\title{
Explanatory Power of Earnings Management Models
}

\author{
Zdenko Metzker ${ }^{1}$, and Anna Siekelova ${ }^{2, *}$ \\ ${ }^{1}$ Faculty of Management and Economics, Center for Applied Economic Research, Tomas Bata \\ University in Zlín, Czech Republic \\ ${ }^{2}$ Faculty of Operation and Economics of Transport and Communications, Department of Economics, \\ University of Zilina, Slovakia
}

\begin{abstract}
.
Research background: Authors deal with the current issue of Earnings Management (hereafter „EM“). It can be said that the emphasis on this issue is constantly growing, especially abroad. Under the condition of Slovak economy, earnings management practices are considered to be a currently developing issue. Based on the globalization, EM practices, models and techniques created abroad are also reaching European countries. Mainly after the recent economic fluctuations caused by financial crisis or COVID19 , the application of earnings management principles in companies with an effort to achieve a balanced profit can be assumed. Within studies or researches, there are many earnings management models. Most of them were created abroad. It means in different economic conditions. There is therefore a question of their use in the conditions of the Slovak economy. Particular importance is their explanatory power, which they achieve in different economic conditions than those in which they arose.

Purpose of the article: The aim of the paper is to test the explanatory power of selected foreign models in the Slovak Republic.

Methods: Statistical methods used in selected EM models (regression, Mann-Whitney nonparametric test); adjusted $\mathrm{R}$ square predicted sign of a variable, standard deviation significance level of model to verify the explanatory power of selected models.

Findings \& Value added: The added value of the contribution is in the testing of the explanatory power of selected foreign models in other economic conditions in which they were created.
\end{abstract}

Keywords: accruals; earnings; earning management; model; explanatory power

JEL Classification: $M 41 ; M 42 ; F 63$

\footnotetext{
*Corresponding author: anna.siekelova@,fpedas.uniza.sk
} 


\section{Introduction}

Within the academic community there is no uniform definition of Earnings Management. Despite the fact that the initial studies dealing with EM issue were developed in 1960s, it is not yet a completely researched issue. One of the first authors dealing with EM issue was Copeland. Copeland described EM as compensating for year-on-year fluctuations in profits by moving it from the most successful periods, where profits are highest to less successful period where profits are lowest, which is intended to mitigate these fluctuations. [1] Authors Callao state that EM issue is a complex problem solved differently depending on the opinions of scientists. [2]

Within studies many definitions of earnings management can be found. Earnings management is described as a tool used by managers to achieve their goals. It is also one of the most used forms of how to manipulate profits. Its essence is to influence the financial statements, related management and decision-making processes. [3-7] Earnings management focuses on increasing (or reducing) earnings or profits per share through aggressive accounting tactics. [8-9] Mahjoub and Miloudi [10] defined Earnings management as any profit management decision within the law, that provides value to the company's stakeholders.

To compare the different opinions of several authors about EM issue, the authors Ronen and Yaari [11] divided EM practices into three basic types, namely white, gray and black. White Earnings Management is defined as the use of flexibility in the choice of accounting method used to signal the future cash flows of the company. Gray Earnings Management is the choice of an opportunistic or economically efficient way of accounting. Black Earnings Management is the way of using accounting tricks designed to distort or reduce the transparency of financial statements. Studies tending to a less negative way of perceiving EM are mainly from recent decades. These are studies by the authors Beneish (published in 2001), Sankar and Subramanyam (published in 2001), Scott (published in 2003) or Fields, Lys and Vincent (published in 2001). Older studies by the authors (Healy, Wahlen, Levitt, Shipper, Tzur or Yaari) perceive earnings management initiatives as an effort by the company to reduce the transparency of the profit reported in the financial statements.

Two types of earnings management can be distinguished, namely real earnings management and accrual-based earnings management. Earnings management realized by using accounting principles is called accrual-based earnings management [12]. On the other hand, the earnings management realized through real operating activities is called real earnings management [13]

In their publication, authors focused on incentives that lead managers to earnings management. They point to the existence of three basic incentives that encourage managers to manage reported earnings, namely:

- incentives from managers,

- incentives from the company,

- incentives from financial analysts and investors. [14]

Based on the research, earnings management initiatives from managers can be divided into three main categories:

1.To report a profit as close as possible to the analysts' forecast.

2. To maintain the company's performance or "smooth results".

3. To report positive results.

This research is supported by author Healy. Their study also adds another point:

4. The regulatory incentive in an effort to reduce interventions as well as tax planning. [15]

Authors Lamrani, Chan and Gao deal with EM incentives from investors. This means that executives use EM techniques to do not disappoint the investors themselves. This theory is 
justified by the desire to maintain the good reputation of the company by realizing its obligations to the company's stakeholders. Managers thus use the EM tool to hide the real value of the company to encourage investors to invest in the company as well as to influence investors regarding the development and future perspective of the company.

The author Mard describes an interesting view in his study. He claims that EM serves to achieve a psychological result - this hypothesis has the basis in marketing. The author states that a product that costs $199 €$ will be more attractive than a product that cost $201 €$. The author used the same principle, but reversed this process, saying that a manager in the company with a result of $201 €$ will be better valued than with a manager in a company with a result of $199 €$. Individuals remember the first number in particular. Therefore, managers manipulate profits upwards. [16]

The issue of earnings management is connected with the issue of its measurement. Various models for measuring EM can be found in the available literature. Most of them were created abroad. It means in different economic conditions. There is therefore a question of their use in the conditions of the Slovak economy. Particular importance is their explanatory power, which they achieve in different economic conditions than those in which they arose. The aim of the paper is to test the explanatory power of selected foreign models in the Slovak Republic.

\section{Methodology}

As was mentioned above, there are several models used to measure EM initiatives in the company. Earnings management models based on the ways to its measurement can be divided to graphical methods based on time series data, mathematical modelling of specific accruals, mathematical modelling of total discretionary accruals using time series data, mathematical modelling of total discretionary accruals using cross-sectional abnormal accruals.

Many authors state that there is currently a wide range of alternative models for measuring earnings management, but the most popular are the Jones model (1991), the modified Jones model (proposed by Dechow, Sloan and Sweeney, 1995), the Theoh, Welch and Wong model (1998), Kasznik's model (1999) and Kothari's model (2005). [17-19] Contribution deals with the explanatory power of these most used earnings management models under the condition of Slovak economy.

It is necessary to detect a sum of discretionary accruals as a part of total accruals. Within current studies, two different ways how to calculate it are described. The balance sheet approach and the statement of cash flows approach can be distinguished. [20] The balance sheet approach is widely used. The sum of total accruals is calculated by using following formula.

$$
T A=\Delta C A-\Delta C L-\Delta C a s h+\Delta S T D-D e p
$$

Where:

$T A \quad$ the sum of total accruals;

$\triangle C A \quad$ the year-on-year change in current assets;

$\triangle C L \quad$ the year-on-year change in current liabilities;

$\Delta$ Cash the year-on-year change in cash and cash equivalents;

$\triangle S T D$ the year-on-year change in the current maturities of long-term debt and other short-term debt included in current liabilities;

Dep depreciation and amortization expenses.

In the next step, variables of earnings management models were calculated based on the following formulas. 
Jones model

Where:

$$
\frac{T A_{i t}}{A_{i t-1}}=\alpha_{0} \frac{1}{A_{i t-1}}+\alpha_{1} \frac{\Delta R E V_{i t}}{A_{i t-1}}+\alpha_{2} \frac{P P E_{i t}}{A_{i t-1}}+\varepsilon_{i t}
$$

$T A_{i t} \quad$ the sum of total accruals in year $t$;

$A_{\text {it-1 }} \quad$ the sum of assets in year $t-1$;

$\triangle R E V_{i t} \quad$ the change in revenues between yearst and $t-1$;

$P P E_{i t} \quad$ the sum of the property, plant \& equipment in year $t$;

$\varepsilon_{i t} \quad$ statistical error;

Modified Jones model

Where:

$$
\frac{T A_{i t}}{A_{\mathrm{it}-1}}=\alpha_{0} \frac{1}{A_{\mathrm{it}-1}}+\alpha_{1} \frac{\Delta R E V_{i t}-\Delta R E C_{i t}}{A_{i t-1}}+\alpha_{2} \frac{P P E_{i t}}{A_{i t-1}}+\varepsilon_{i t}
$$

$\triangle R E C_{i t} \quad$ the change in receivables between years $t$ and $t-1$.

Theoh, Welch and Wong model

Where:

$$
\frac{T A_{i t}}{A_{i t-1}}=\alpha_{0} \frac{1}{A_{\mathrm{it}-1}}+\alpha_{1} \frac{\Delta S A L E_{i t}-\Delta R E C_{i t}}{A_{i t-1}}+\varepsilon_{i t}
$$

$\triangle S A L E i t \quad$ the change in sales between years $t$ and $t-1$.

Kasznik's model

Where:

$$
\frac{T A_{i t}}{A_{i t-1}}=\alpha_{0} \frac{1}{A_{i t-1}}+\alpha_{1} \frac{\Delta R E V_{i t}}{A_{i t-1}}+\alpha_{2} \frac{P P E_{i t}}{A_{i t-1}}+\alpha_{3} \frac{\Delta C F O_{i t}}{A_{i t-1}}+\varepsilon_{i t}
$$

$\triangle C F O_{i t} \quad$ the change in operating cash flow between years $t$ and $t-1$.

\section{Kothari's model}

Where:

$$
\frac{T A_{i t}}{A_{i t-1}}=a_{0} \frac{1}{A_{i t-1}}+\alpha_{1} \frac{\Delta R E V_{i t}-\triangle R E C_{i t}}{A_{i t-1}}+\alpha_{2} \frac{P P E_{i t}}{A_{i t-1}}+\alpha_{3} \frac{R O A_{i t-1}}{A_{i t-1}}+\varepsilon_{i t}
$$

$R O A_{i t-1} \quad$ return on assets in year $t-1$.

\begin{tabular}{|c|c|c|}
\hline Criterion & Calculation & Author/Authors \\
\hline $\begin{array}{l}\text { Adjusted coefficient of } \\
\text { determination (adjusted } r \\
\text { square) }\end{array}$ & $1-\left[\frac{\left(1-r^{2}\right)(N-1)}{N-k-1}\right.$ & $\begin{array}{l}\text { Key, Peasnell, } \\
\text { Burgstahler,, etc. }\end{array}$ \\
\hline Predicted sign of a variable & $\begin{array}{c}\text { Jones model } \\
\Delta \text { REV (predicted }+ \text { ) } \\
\text { PPE (predicted -) } \\
\text { Modified Jones model } \\
\Delta \text { REV }-\Delta \text { REC (predicted +) } \\
\text { PPE (predicted -) }\end{array}$ & $\begin{array}{l}\text { Peasnell, McNichols, } \\
\text { Bartov, Kothari, etc. }\end{array}$ \\
\hline
\end{tabular}

Based on studies, several criteria are used to estimate the explanatory power of the model in the EM initiatives calculation. Table 1 shows these criteria, their values, and authors of the studies who used these criteria to describe the explanatory power.

Table 1. The most frequently used calculation methods of EM chronologically arranged. 


\begin{tabular}{|c|c|c|}
\hline & $\begin{array}{c}\text { Theoh, Welch and Wong model } \\
\Delta \mathrm{SALE}-\Delta \mathrm{REC} \text { (predicted }+ \text { ) } \\
\text { Kasznik's model } \\
\Delta \mathrm{REV} \text { (predicted }+ \text { ) } \\
\text { PPE (predicted -) } \\
\Delta \mathrm{CFO} \text { (predicted -) } \\
\text { Kothari's model } \\
\Delta \mathrm{REV}-\Delta \mathrm{REC} \text { (predicted }+ \text { ) } \\
\text { PPE (predicted -) } \\
\text { ROA (predicted -) }\end{array}$ & \\
\hline Standard deviation & $\begin{array}{c}\text { St.dev } \frac{1}{a_{i t-1}} \\
\text { St.dev } \frac{\Delta r e v_{i t}-\delta r e c_{i t}}{A_{i t-1}} \\
\text { St.dev } \frac{P p e_{i t}}{A_{i t-1}}\end{array}$ & $\begin{array}{c}\text { Dechow, McNichols, } \\
\text { Jeanjean, Bartov, Kothari, } \\
\text { etc. }\end{array}$ \\
\hline Significance level of model & $\begin{array}{c}F-\text { test of statistical } \\
\text { significance was used } \\
\text { The following hypotheses were } \\
\text { set: } \\
-\quad h_{0}: \text { the model is not } \\
\text { statistically significant; } \\
-\quad h_{1}: \text { the model is } \\
\text { statistically significant } * *\end{array}$ & Mcnichols, Jeanjean, etc. \\
\hline
\end{tabular}

Note: $* R^{2}$ is the coefficient of determination, $n$ is the number of elements in the sample, $k$ is the number of independent variables. ** If the calculated $\mathrm{p}$-value is less than the selected significance level $\alpha=0.05$, the null hypothesis is rejected and hypothesis $\mathrm{H}_{1}$ is accepted. All calculations were performed using statistical analysis software in Excel XLSTAT and are presented in the next part of the paper.

The aim of the paper is to test the explanatory power of selected foreign models in the Slovak Republic Data for research were obtained from the Amadeus database providing standardized annual accounts (consolidated and unconsolidated), ownership data, sectoral activities, and financial ratios. Obtained data cover financial statements of Slovak entities for 2018. The dataset consists of 950 companies.

\section{Results and Discussion}

Based on previous formulas criteria used to estimate the explanatory power of the model in the EM initiatives were calculated within data. Table 2 shows the results.

Table 2. Explanatory power of the selected earnings management models.

\begin{tabular}{|l|c|c|}
\hline Criterion & Model & Value \\
\hline & Jones model & 0.1038 \\
\hline
\end{tabular}




\begin{tabular}{|c|c|c|}
\hline \multirow{4}{*}{$\begin{array}{c}\text { Adjusted coefficient of } \\
\text { determination (adjusted } r \\
\text { square) }\end{array}$} & Modified Jones model & 0.13 \\
\hline & $\begin{array}{c}\text { Theoh, Welch and Wong } \\
\text { model }\end{array}$ & 0.06 \\
\hline & Kasznik's model & 0.12 \\
\hline & Kothari's model & 0.11 \\
\hline \multirow{5}{*}{ Predicted sign of a variable* } & Jones model & $\begin{array}{l}0.67 \\
0.82\end{array}$ \\
\hline & Modified Jones model & $\begin{array}{l}0.88 \\
0.79\end{array}$ \\
\hline & $\begin{array}{l}\text { Theoh, Welch and Wong } \\
\text { model }\end{array}$ & 0.54 \\
\hline & Kasznik's model & $\begin{array}{l}0.57 \\
0.33 \\
0.62\end{array}$ \\
\hline & Kothari's model & $\begin{array}{l}0.61 \\
0.48 \\
0.23 \\
\end{array}$ \\
\hline \multirow{5}{*}{$\begin{array}{l}\text { Standard deviation of } \\
\text { individual variables }\end{array}$} & Jones model & $\begin{array}{l}0.09 \\
0.02 \\
0.02 \\
\end{array}$ \\
\hline & Modified Jones model & $\begin{array}{l}0.02 \\
0.03 \\
0.02\end{array}$ \\
\hline & $\begin{array}{c}\text { Theoh, Welch and Wong } \\
\text { model }\end{array}$ & $\begin{array}{l}0.04 \\
0.02 \\
\end{array}$ \\
\hline & Kasznik's model & $\begin{array}{l}0.03 \\
0.04 \\
0.04 \\
0.02\end{array}$ \\
\hline & Kothari's model & $\begin{array}{l}0.02 \\
0.02 \\
0.03 \\
0.05\end{array}$ \\
\hline \multirow{5}{*}{ Significance level of model } & Jones model & $\begin{array}{c}\text { The model is statistically } \\
\text { significant }\end{array}$ \\
\hline & Modified Jones model & $\begin{array}{c}\text { The model is statistically } \\
\text { significant }\end{array}$ \\
\hline & $\begin{array}{c}\text { Theoh, Welch and Wong } \\
\text { model }\end{array}$ & $\begin{array}{c}\text { The model is statistically } \\
\text { significant }\end{array}$ \\
\hline & Kasznik's model & $\begin{array}{c}\text { The model is statistically } \\
\text { significant }\end{array}$ \\
\hline & Kothari's model & $\begin{array}{c}\text { The model is statistically } \\
\text { significant }\end{array}$ \\
\hline
\end{tabular}

Note: * Given as the percentage agreement of the predicted sign with the results within the data. 


\section{Conclusion}

Within literature, models for earnings management measurement can be found. have been developed in order to measure degree of earnings management. Most of them were created abroad. It means in different economic conditions. There is therefore a question of their use in the conditions of the Slovak economy. Particular importance is their explanatory power, which they achieve in different economic conditions than those in which they arose. The aim of the paper is to test the explanatory power of selected foreign models in the Slovak Republic. Authors describe explanatory power of the most used earnings management models the Jones model (1991), the modified Jones model (proposed by Dechow, Sloan and Sweeney, 1995), the Theoh, Welch and Wong model (1998), Kasznik's model (1999) and Kothari's model (2005). Explanatory power was measured by selected indicators described in table 1 . Based on the results, the highest explanatory power due to the adjusted coefficient of determination has Modified Jones model. On the other hand, the lowest has Theoh, Welch and Wong model. Modified Jones model has the highest explanatory power due to the predicted sign indicator, too. Due to the standard deviation of variables the results are inconclusive. The indicator "intercept" achieves higher variability within Jones model. All used models are statistically significant.

The modified Jones model is a worldwide model used in EM measurements. Its explanatory power even in the conditions of the Slovak Republic is adequate.

This paper was financially supported by the VEGA 1/0121/20: Research of transfer pricing system as a tool to measure the performance of national and multinational companies in the context of earnings management in conditions of the Slovak Republic and V4 countries.

\section{References}

1. Copeland, R. (1968). Income Smoothing. Journal of Accounting Research. 6, 101-116.

2. Callao, S. (2014). Debates and studies on earnings management: A geographical perspective. Zeszyty Teoretyczne Rachunkowości, 131(75), 145-169.

3. Svabova, L., Michalkova, L. (2020). The impact of Data structure on classification ability of financial failure prediction model. 19th International Scientific Conference Globalization and Its Socio- Economic Consequences - Sustainability in the GlobalKnowledge Economy. Rajecke Teplice, Slovakia.

4. Misankova, M., Spuchlakova, E., Frajtova-Michalikova, K. (2015). Determination of default probability by loss given default. Procedia Economics and Finance. 26, 411-417.

5. Dechow, P. M., Sloan, R. G. (1991). Executive incentives and the horizon problem: An empirical investigation. Journal of Accounting and Economics. 14(1), 51-89.

6. Kang, S. H., Sivaramakrishnan, K. (1995). Issues in testing earnings management and instrumental variable approach. Jornal of Accounting Research. 33(2), 353-367.

7. Kasznik, R. (1999). On the Association between Voluntary Disclosure and Earnings Management. Journal of Accounting Research. 37(1), 57-81.

8. Valaskova, K., Kliestik, T., Kovacova, M. (2019). Assessment of selected models of earnings management in economic conditions of Slovakia. Proceedings of the 33rd International-Business-Information-Management-Association (pp. 3922-3931). Granada, Spain.

9. Whittle, T., Gregova, E., Podhorska, I., Rowland, Z. (2019). Smart manufacturing technologies: Data-driven algorithms in production planning, sustainable value Creation, 
and operational performance improvement. Economics, Management, and Financial Markets. 14(2), 52-57.

10. Mahjoub, I., Miloudi, A. (2015). Earnings management: A review of literature. Euro and the European Banking System: Evolutions and Challenges (pp. 691-703). Alexandru Ioan Cuza University of Iaşi, Romania.

11. Ronen, J., Yaari, V. (2008). Earnings management. Emerging insights in theory, practice and research. New York: Springer.

12. Smith, E. D. (1976). The effect of the separation of ownership from control on accounting policy decisions. The Accounting Review. 51(4), 707-723.

13. DeAngelo, L. E. (1986). Accounting numbers as market valuation substituted: a study of management buyouts of public stockholders. The Accounting Review. 61(3), 400-420.

14. Roychowdhury, S. (2006). Earnings management through real activities manipulation. Journal of Accounting and Economics. 42(3), 335-370.

15. Healy, P. M. (1985). The effect of bonus schemes on accounting decisions. Journal of Accounting and Economics. 7(1-3), 85-107.

16. Mard, Y. (2003). Performance comptable et gestion des résultats. 24ÈME CONGRES DE L'AFC - Identification et maîtrise des risques: enjeux pour l'audit, la comptabilité et le contrôle de gestion. Université Jean Moulin, Lyon.

17. Hepworth, R. S. (1953). Smoothing Periodic Income. The Accounting Review. 28(1), 32 -39 .

18. Gordon, M. J. (1964). Security and investment: Theory and evidence. The Journal of Finance. 19(4), 607-618.

19. Podhorska, I., Valaskova, K., Stehel, V., Kliestik, T. (2019). Possibility of Company Goodwill Valuation: Verification in Slovak and Czech Republic. Management \& Marketing-Challenges for the Knowledge Society. 14(3), 338-356.

20. Hudakova, M., Masar, M., Luskova, M., Patak M.R. (2018). The dependence of perceived business risks on the size of SMEs. Journal of Competitiveness. 10(4), 54-69. 